\title{
Effect of sedimentation volume on productivity and dwelling time of ships at bom baru port
}

\author{
Putranto Dinar DA ${ }^{1 *}$, and Buchari Erika ${ }^{2}$ \\ ${ }^{1}$ Civil Engineering,Faculty of Engineering, University of Sriwijaya, Km. 32,Inderalaya Highway \\ Street, South Sumatera, Indonesia. \\ ${ }^{2}$ Post Graduate Program, Faculty of Engineering, University of Sriwijaya, Bukit Besar, Palembang, \\ Indonesia
}

\begin{abstract}
Many ports in Indonesia who have problems with limited dock land, yard and warehouse and equipment. There is a dock that has good equipment, but Yard Occupancy and Berth Occupancy ratio are high ratio. Boom Baru port in the city of Palembang, in Indonesia, has good hinterland and the number of ship visits is quite high, but can not increase productivity or capacity of the port due to the rapid sedimentation of the port basin and land constraints to accumulation of goods. In this study, the method used to determine the condition of the real problems of sedimentation conducted through analysis of sediment concentration and sediment discharge a total of either scenario sediment from upstream (river) as well as the source of sediments estuary (port basin) ${ }^{[1]}$. By knowing the pattern of flow and sediment caracteristic process of sedimentation and erosion in the estuary, can be calculated by the method of Yang ${ }^{[2]}$. The calculation and analysis show that the sedimentation on the Musi river is high enough where the sludge reaches $40 \mathrm{~cm} / \mathrm{month}$. While the volume of sedimentation in the pools of Boom Baru port calculated using the Yang method, amounting to $13,081.42 \mathrm{~m} 3 /$ year.
\end{abstract}

\section{Introduction}

The length of river port services can be grouped into two categories, namely Waiting Time and Dwelling Time. Problems, dwelling time of record in 4 (four) national ports in the case of mal administration examined Ombudsman (2014) as follows: (1) delay is protracted, namely the length of the necessary permits prohibitions and restrictions (Lartas) from the relevant authorities, the lengthy process of publishing Identification Number Customs Office (NIK), the uncertainty of the time service physical examination of the examination process until a response from the Directorate General of Customs and Excise, uncertainty container classification and customs valuation which causes delay in clearance of containers; (2) Deviation procedures, including services at the Port was not optimal 24/7 and quarantine inspection is carried out outside the port area or container that is already out of the customs territory despite still waiting for test results, laboratories but entered the warehouse owner; (3) Any competent examiner's performance including the container on

${ }^{*}$ Corresponding author: dwianugerah@yahoo.co.id 
the red line (behandle) and quarantine inspectors were not optimal, and not all human resources (HR) master of regulation; (4) Abuse of authority committed by some individuals, including the issuance of the Memorandum of Correction (NOTUL), the persons who facilitate or complicate expenditure containers; (5) Charges not authorized by the person, including service during the ascending lower (lift on - lift off) container terminal, forklift operator, opening the container in behandle, the withdrawal process container into behandle, physical examination process up to the issuance of SPPB.

Compounding the problem, the waiting time (waiting time) long in port caused by several factors including the weather factor, sedimentation, tides, loading and unloading equipment damage cranes and others. There were 9 (nine) types of waiting time (waiting time) at the Port, namely: (1) Approach Time (AT), is the time it takes ships from anchoring locations to tie the rope on the dock; (2) BerthTime (BT), is a period in the dock since ships first fastening strap (first line) until the ship off her leash (last line), consisting of: (a) Berth Working Time (BWT), namely working hours are available for loading and unloading boats at the dock; (b) Effective Time (ET)/Operating Time (OT), which is the amount of time used for loading and unloading activities at the dock; (c) Idle Time (IT), the time wasted during the ship is in dock due to the effects of weather and loading and unloading equipment damaged; (d) Not Operation Time (NOT), that time does not work planned during the ship at dock (preparation B/M and the rest of work); and (e) Berth Occupancy Ratio (BOR) or the level of use Pier, is comparison between the use of the dock to the time available in a specific time period that is expressed in percentage; (3) Turn Around Time (TRT) is the amount of time for the ship was in port, counted since the ship arrived at the location of anchorage outside the harbor waters, then dry dock and load and unload until the ship departs back. Turn Around Time (TRT) is called the Dwelling Time. Dwelling Time is the waiting time of ships in port or rather the time spent in port ship in order the process of unloading or loading of goods; (4) Postpone Time (PT) is a waiting time caused by administrative procedures in ports are calculated from the anchor to ship finished unloading at the dock. According to UNCTAD (United Nations Conference On Trade and Development), the level of use of the pier (BOR) can not exceed the value (\%) that has been set.

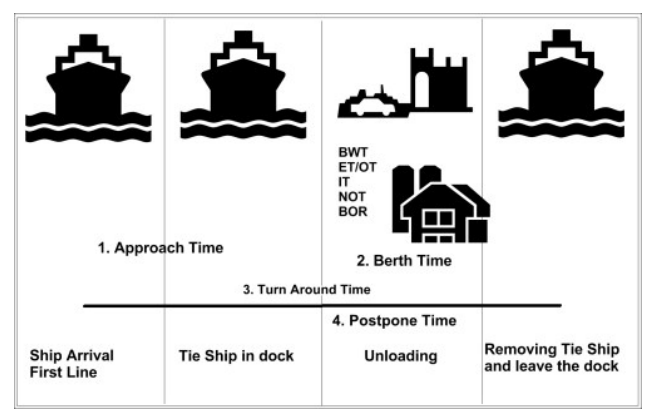

(1)

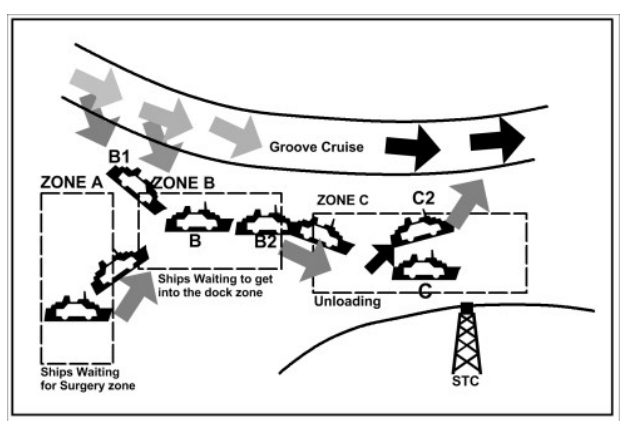

(2)

Fig.1. Schematically wait time ships in the port (1) waiting time at pier; (2) zone ships in port

On this basis, the problem is: (1) How big is the volume and distribution of sedimentation occurred in waters around Boom Baru port basin, causing water levels are the lowest that can be passed vessel to be reduced; (2) How can flow management port waters of rivers and basin in order to obtain the waiting time shorter ships to load and unload.

The purpose of this research is: (1) to analyze the distribution and volume of sedimentation in the waters around the port basin, and the river channel; (2) Managing the 
flow of cruise ships around the port basin to obtain the shortest time to load and unload due to tidal influence there. It required the making of port planning model in improving productivity and stevedoring services at the port so it can reduce the dwelling time of service multimodal transportation system that is integrated, effective and efficient.

\section{Methodology}

\subsection{Research location}

Research carried out at the port of Boom Baru, Palembang on Indonesia with geographical location coordinates between $104^{\circ} 46^{\prime} 30^{\prime \prime}-104^{\circ} 47^{\prime} 0^{\prime \prime}$ East and between $2^{\circ} 58^{\prime} 48^{\prime \prime}-2^{\circ} 59^{\prime}$ 05" Southern hemisphare. Boom Baru port, is river port built since the days before independence, which serves as the loading and unloading of goods on a large scale that goes to the South Sumatra province. Initial Condition Boom Baru port development, earmarked for ships weighing over 10,000 DWT with the port basin depth is $15 \mathrm{~m}$ (PT. Pelabuhan Indonesia II).

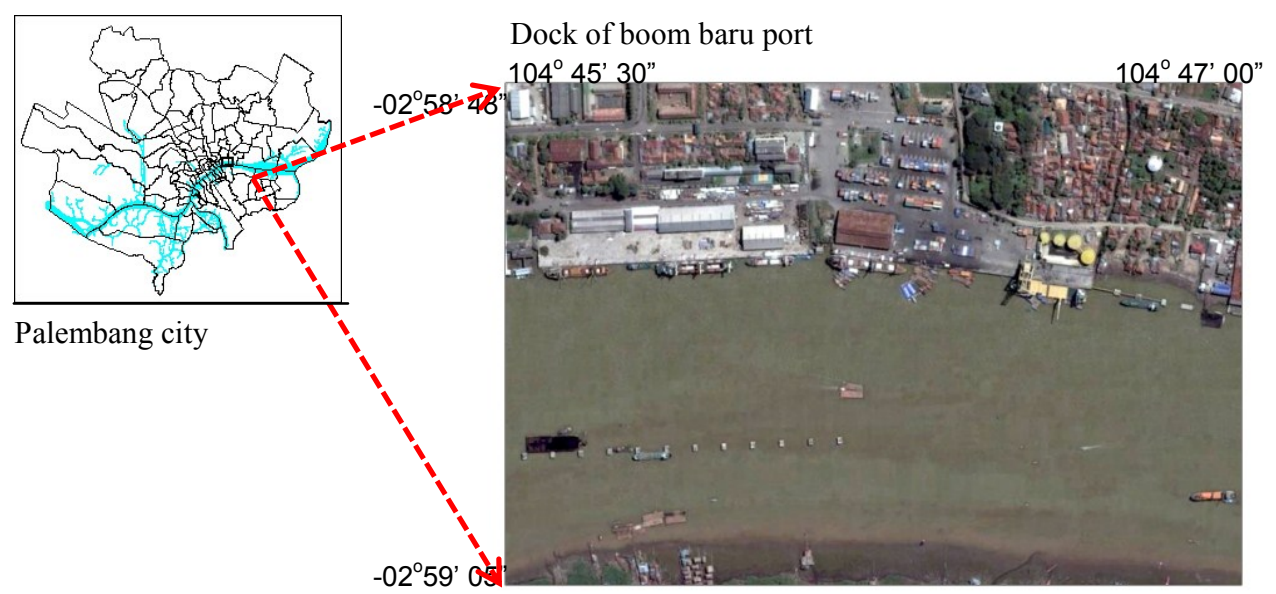

Fig. 2. Research sites of bom baru port, Palembang Cities

\subsection{Material and methods}

The study was conducted by using the following steps: (1) collecting field data in the form of measurement bathymetry using the tool Echosounder conducted transects along and width of port basin $(500 \times 500) \mathrm{m}$, with distance measurements every $25 \mathrm{mx} 25 \mathrm{~m}$, sampling sediment drift and sediment riverbed at each cross-section is done once and then conducted laboratory tests to determine the grain size, flow measurement using current meter on each cross-section and low tides conducted over 15 days; (2) Analysis of hydrooceanography, sediment characteristics analysis and flow modeling using DIVAST-2D models; (3) Calibration models to determine the parameters of empirical field, which is obtained from laboratory analysis of the results of sampling field.

Divast 2-D model of a hydrodynamic modeling (waves and currents), sediment transport, temperature and pollutants. DIVAST 2-D model is the average depth of the horizontally oriented in the $\mathrm{x}$ and $\mathrm{y}$ directions. DIVAST models also use finite difference methods that are solved by using the Fortran language ${ }^{[3]}$.

The equation used is as follows,

a) The equation of hydrodynamics wave number vector equation: 


$$
\frac{\partial K_{i}}{\partial t}+\left[C_{g} \frac{K_{j}}{k}+U_{j}\right] \frac{\partial K_{i}}{\partial x_{j}}+\frac{\sigma G}{2 h} \frac{\partial h}{\partial x_{i}}+\frac{C_{g}}{2 k A}\left[\frac{1}{A} \frac{\partial A}{\partial x_{i}} \frac{\partial^{2} A}{\partial x_{j}^{2}}-\frac{\partial^{3} A}{\partial x_{i} \partial x_{j}^{2}}\right]+K_{j} \frac{\partial U_{j}}{\partial x_{i}}=0
$$

The amplitude of the wave equation :

$$
\frac{\partial A}{\partial t}+\frac{1}{2 A} \frac{\partial}{\partial x_{i}}\left\{A^{2}\left[\frac{C_{g}}{k} K_{i}+U_{i}\right]\right\}+\frac{S_{i j}}{\rho g A} \frac{\partial U_{j}}{\partial x_{i}}+C^{a} A^{2}=0
$$

Continuity equation :

$$
\begin{gathered}
\frac{\partial \varsigma}{\partial t}+\frac{\partial(H U)}{\partial x}+\frac{\partial(H V)}{\partial y}=0 \\
H=h+\varsigma
\end{gathered}
$$

Momentum equation :

$$
\begin{gathered}
\frac{\partial(H U)}{\partial t}+\frac{\partial(\beta H U)}{\partial x}+\frac{\partial(\beta H U V)}{\partial y}=f H V-g H \frac{\partial \varsigma}{\partial x}-\frac{g H^{2}}{2 \rho \partial} \frac{\partial \rho}{\partial x}-\frac{\tau_{w x}-\tau_{b x}}{\rho}+ \\
\overline{v_{h} H}\left[\frac{\partial^{2} U}{\partial x^{2}}+\frac{\partial^{2} u}{\partial y^{2}}\right]+\frac{1}{\rho}\left[\frac{\partial S_{x x}}{\partial x}+\frac{\partial S_{x y}}{\partial y}\right] \\
\frac{\partial(H V)}{\partial t}+\frac{\partial(\beta H U V)}{\partial x}+\frac{\partial\left(\beta H V^{2}\right)}{\partial y}=-f H U-g H \frac{\partial \varsigma}{\partial y}-\frac{g H^{2}}{2 \rho} \frac{\partial \rho}{\partial y}-\frac{\tau_{w y}-\tau_{b y}}{\rho}+ \\
\left.\frac{v_{h} H}{\partial x^{2}}+\frac{\partial^{2} V}{\partial y^{2}}\right]+\frac{\partial^{2} V}{\rho}\left[\frac{\partial S_{x y}}{\partial x}+\frac{\partial S_{y y}}{\partial y}\right]
\end{gathered}
$$

Where : $\zeta=$ water level; $\mathrm{U}, \mathrm{V}=$ the average speed of the depth of $\mathrm{x}$ and $\mathrm{y} ; \mathrm{H}=$ the total depth of water; $\mathrm{h}=$ the depth of still water, $\mathrm{A}=$ wave amplitude, $\mathrm{Cg}=$ wave velocity in groups, $\beta=$ momentum coefficient; $\tau_{\mathrm{wx}}, \tau_{\mathrm{wy}}=$ shear stress components on the surface due to wind in the direction of $\mathrm{x}$ and $\mathrm{y} ; \tau_{\mathrm{bx}}, \tau_{\mathrm{by}}=$ shear stress components at the base in the direction of $\mathrm{x}$ and $\mathrm{y} ; \mathrm{v}=$ eddy viscosity; $\mathrm{S}_{\mathrm{xx}}, \mathrm{S}_{\mathrm{xy}}, \mathrm{S}_{\mathrm{yy}}=$ stress caused by radiation wave field.

b) Sediment transport equations and basic elevation changes

This model explains patterns of sediment movement, who moderated the equation in the form of convection-diffusion equation that already included the erosion and deposition rate. The equation is written,

$$
\frac{\partial(H C)}{\partial t}+\frac{\partial(\alpha H U C)}{\partial x}+\frac{\partial(\alpha H V C)}{\partial y}=\frac{\partial}{\partial x}\left(H \varepsilon \frac{\partial C}{\partial y}\right)+\frac{\partial}{\partial y}\left(H \varepsilon \frac{\partial C}{\partial y}\right)+H S_{c}
$$

By giving the effect of concentration as in Van Rijn ${ }^{[4]}$, the formulation of basic topographical changes based on the completion of the sediment continuity equation can be written, 


$$
\frac{\partial z_{b}}{\partial t}+\frac{1}{\rho_{s}\left(1-n_{p}\right)}\left[\frac{\partial\left(D S_{t}\right)}{\partial t}+\frac{\partial q_{t x}}{\partial x}+\frac{\partial q_{t y}}{\partial y}\right]=0
$$

where :

$$
\begin{aligned}
& q_{t x}=q_{s, x}+q_{b, x} \\
& q_{t y}=q_{s, y}+q_{b, y}
\end{aligned}
$$

where :

$$
\begin{array}{ll}
\mathrm{Z}_{\mathrm{b}} & =\text { bottom elevation, } \mathrm{n}_{\mathrm{p}}=\text { porrossities and } \\
\mathrm{q}_{\mathrm{tx}} \text { dan } \mathrm{q}_{\mathrm{ty}} & =\text { the rate of total sediment transport in the } \mathrm{x} \text { and } \mathrm{y} \text { directions. } \\
\mathrm{S}_{\mathrm{c}} & =\text { source terms in connection with erosion and deposition. } \\
& =\mathrm{D}-\mathrm{E}
\end{array}
$$

c) Temperature equation

$$
\frac{\partial(H T)}{\partial t}+\frac{\partial(H U T)}{\partial x}+\frac{\partial(H V T)}{\partial y}=\frac{\partial}{\partial x}\left(H \varepsilon \frac{\partial T}{\partial y}\right)+\frac{\partial}{\partial y}\left(H \varepsilon \frac{\partial T}{\partial y}\right)+H T_{c}
$$

Where : $\mathrm{H}=$ total depth of flow, $\mathrm{U}, \mathrm{V}=$ the average speed of flow depht, $\mathrm{C}=$ Concentration of sediment, $\mathrm{D}=$ deposition, $\mathrm{E}=$ erosion, $\mathrm{T}=$ average depth of water temperature, $\varepsilon=$ depth- averaged eddy diffusity, $\mathrm{T}_{\mathrm{c}}=$ source termsin respect of external influences on temperature feedback.

According to $\mathrm{Yang}^{[5]}$, in the calculation of sediment transport need to be seen sediment load tpe to be counted. In this case the need to classify the type of sediment, namely: (1) Bed Load, particles are transported by means of rolling, sliding and jumping; (2) Suspended Load, is transported by floating particles. Yang ${ }^{[5]}$ discusses the basic assumptions used in the equations derived sediment transport. It was concluded that the rate of sediment transport can be determined from the discharge of water, the flow rate of the average - average, energy slope or shear stress. The equation used :

$$
\begin{gathered}
\log C t=5,435-, 268 \log \frac{\omega d}{v}-, 457 \log \frac{\mathrm{U} *}{\omega}+\left(1,799-, 409 \log \frac{\omega d}{v}-\right. \\
\left.\left., 314 \log \frac{\mathrm{U} *}{\omega}\right) \log \frac{v s}{\omega}-\frac{v c r S}{\omega}\right) \\
\mathrm{U}^{*}=(\mathrm{g} \times \mathrm{D} \times \mathrm{S})^{1 / 2}
\end{gathered}
$$

Where shear rate $\left(\mathrm{U}^{*}\right)$ is Reynolds shear speed figures are :

$$
\operatorname{Re}=\frac{\mathrm{U}^{*} \times \mathrm{d}_{50}}{v}
$$

for $\quad 1.2<\frac{\mathrm{U}^{*} \times \mathrm{d}}{v}<70$, then

$$
\frac{2,5}{\log \left(\frac{U^{*} x d_{50}}{v}\right)-0,06}+0,06
$$


for $\quad 70<\frac{\mathrm{U}^{*} \times \mathrm{d}}{v}$, then $\quad \frac{\mathrm{V}_{\mathrm{cr}}}{\omega}=2.05$

where :

$\mathrm{Ct}=$ Total of sediment concentration

$\mathrm{V} \quad=$ speed of flow $(\mathrm{ft} / \mathrm{s})$

$\Omega=$ speed of sediment falls ( $\mathrm{ft} / \mathrm{s}$ )

$\mathrm{S} \quad=$ slope drainage $(\%)$

$\mathrm{D}=$ middle diameter of particle $(\mathrm{ft})$

Vcr $\quad=$ critical speed

$v=$ Viscosity Kinematic $\left(\mathrm{ft}^{2} / \mathrm{s}\right)$

$\mathrm{U}^{*} \quad=$ sheare rate $(\mathrm{ft} / \mathrm{s})$

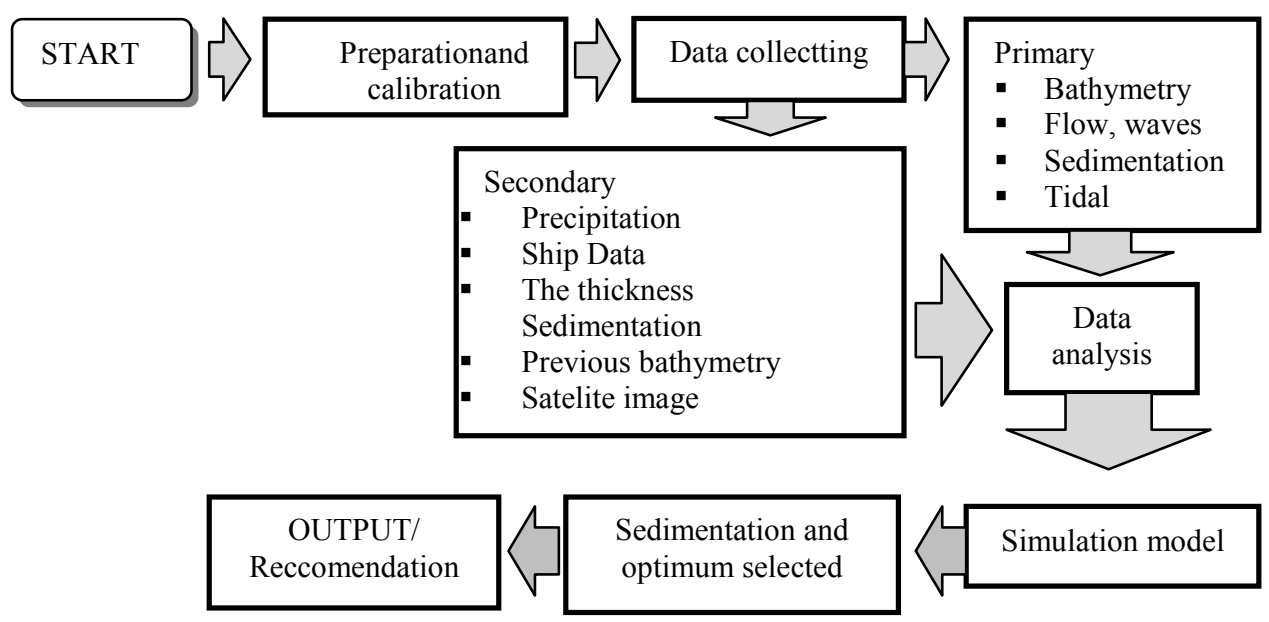

Fig. 3. Interaction diagram process assessment model sedimentation at port basin

\section{Results and discussion}

\subsection{Depht, tide and currents}

Conditions Musi river around the port of Boom Baru, generally shallow and very gentle and the general condition of the area around the port is under the influence of sedimentation due to the presence of several rivers that carry sediments and slopes of bottom waters. The depth of the waters around the port of Boom Baru measurement results show that the depth range (5.5 to 15.0$) \mathrm{m}$, with an average depth of $9.91 \mathrm{~m}$ (spreads horizontally depth can be seen in Figure 4. The most shallow waters found around the docks $(5.2 \mathrm{~m})$, while the deepest waters found in the middle of the river flow $(15.6 \mathrm{~m})$.

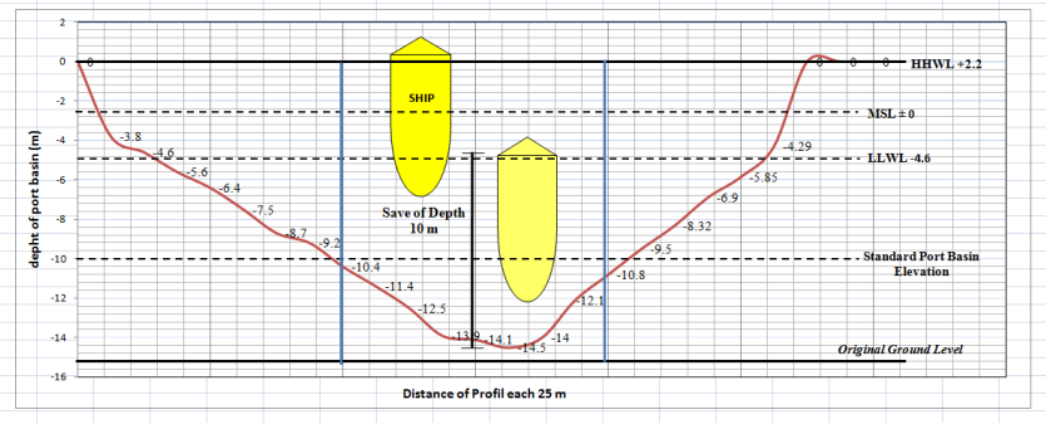

Fig.4. Depth and cross section of port basin 
Port basin cross-sectional shape, of conditions such as bathymetry data above, can be described, that during low tide so the water level only reached (4-5) $\mathrm{m}$ from the mean sea levels. While during high tide, the water level can reach a height (15-16) $\mathrm{m}$ from the mean sea levels. Based on observations of tides, suggesting that this type of tidal influence is of a single type, meaning that in one day occurred one high tide and one low tide. The highest tide happened at about 20:00 to 5:00 pm, average as high as 11.87 to $15.56 \mathrm{~m}$. While the lowest tide occurred at 7:00 to $14: 00 \mathrm{pm}$, approximately $4.6-6.6 \mathrm{~m}$.

Based on the above data, it's the height of the water surface in accordance traversed ships would load and unload at the port basin to adjust the distance of the hull weighing 10,000 DWT, the time available is only about 10 hours. This condition causes the adjustment time of arrival of the vessel into dry dock to be disrupted, because the waiting time of the tide.

Based on data from BMG from 2006-2016 year, average wind speed during the month of October is $3.27 \mathrm{Km} / \mathrm{h}=0.907 \mathrm{~m} / \mathrm{s}$ with an average direction of wind movement towards the southeast. Current measurement port basin waters around Boom Baru port obtained current velocity ranges from 0.02 to $0.306 \mathrm{~m} / \mathrm{s}$, with an average speed of flow during the observation is $0.159 \mathrm{~m} / \mathrm{s}$.

\subsection{Total sediment load}

To know the total load of sediment transport, then the calculation is based on parameters obtained in the port basin through sampling and testing of large grain sediment load carried out in laboratories ${ }^{[6]}$. Properties Index sediment testing includes testing sieve analysis which aims to get the size of a grain escaped percent $50 \%\left(\mathrm{D}_{50}\right)$, and a specific gravity of sediment contained in the port basin ${ }^{[7]}$. Based on the results of data analysis sieve (sieve analysis) of sediment samples in Boom Baru port basin, can be illustrated in the graph of particle diameter (mm) which passes 50\% (Fig. 5), it is known that the grain size of the sediment downstream portion $\mathrm{D}_{50}$ is $0.04 \mathrm{~mm}$ and the upstream side was $0.06 \mathrm{~mm}$. Thus, the average grain size of the sediment $\mathrm{D}_{50}$ in Boom Baru port is $0.05 \mathrm{~mm}$. The result of the calculation of density sediment testing for upstream and downstream obtained an average value of 2.53 grams.

Table 1. Volume of sedimentation boom baru port basin (2005-2014)

\begin{tabular}{l|l}
\hline Year & $\begin{array}{l}\text { Volume of } \\
\text { Sedimentation } \\
\text { (Cm3/year) }\end{array}$ \\
\hline 2005 & $34,609.13$ \\
\hline 2006 & $98,430.13$ \\
\hline 2007 & $62,104.01$ \\
\hline 2009 & $56,739.94$ \\
\hline 2010 & $62,505.72$ \\
\hline 2012 & $75,544.92$ \\
\hline 2013 & $86,512.71$ \\
\hline
\end{tabular}

Sedimentation, can cause several problems including the activity disrupted navigation/maneuvering the vessel either $a t^{[8]}$ : (1) Shipping-In the arrival of a vessel (dock to dock); (2) The activities of loading and unloading of goods; and (3) Shipping-Out is when the ship set sail again (the ship's departure). The depth of each point varies, from one another. The spread of sediment and depth of an uneven harbor that, due to changes in current direction due to the influence of waves and turbulence effects caused by the rotation of the blades (Propeller) Ships in the harbor bottom of the port. 


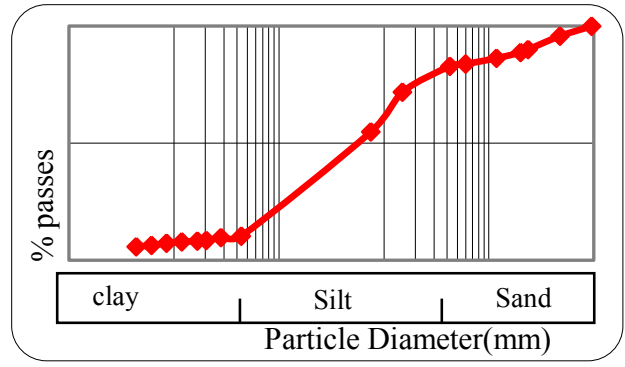

(b) upstream

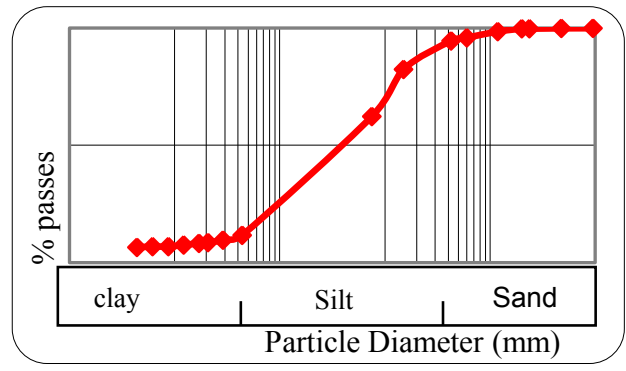

(a) downstream

Fig. 5. Graph distillate passes $50 \%\left(D_{50}\right)$ sediment samples

Figure 6, shows that the depth of the Musi river different between one area to another area with an average depth of $10.88 \mathrm{~m}$. Based on data from Table 1, the conditions shipping channel depth due to sedimentation in the Boom Baru port basin, especially in front of the pier to change every year, which caused fluctuations in the depth of the water level up and down due to sedimentation. The condition of the water surface elevation of the Musi River for five (5) years from 2008 to 2014 and especially in 2014, the average distance between the bottom of the boat (keel) the maximum draft of $7.24 \mathrm{~m}$ when the surface of the bed river less than 10 meters to weight of 15,000 DWT ships. Based on Figure 6, Zone 1-3 at the time of the ship arrived (Shipping-In), Musi river water level at that post or position of the highest water level (HHWL) with a minimum requirement of 7.24 meter draft vessels, the depth $(\mathrm{h})$ port basin at that position is 12.2 meters.

\begin{tabular}{|c|c|c|c|c|c|c|c|c|c|c|c|c|c|c|c|c|c|c|c|c|c|c|c|}
\hline & & & & & & & & & & & 10 & & & & 14 & 5 & 16 & 17 & 18 & 9 & 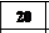 & 21 & \\
\hline & & & & & & & & & & & & & & & & & & & & & 0 & 0 & 0 \\
\hline & & & & & 5 & & & 1 & -5.4 & 38 & -5.43 & \begin{tabular}{|l|}
-5.45 \\
\end{tabular} & 41 & 42 & \begin{tabular}{|l|}
-5366 \\
\end{tabular} & 4 & 95 & -3.8 & 3.65 & 3.7 & 3.65 & 3.6 & 55 \\
\hline & & & & & 4.6 & & & 3 & & & & -5.4 & & & 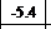 & 53 & & -49 & & 18 & 4.7 & 4.6 & 4.64 \\
\hline & & & & & 53 & & & -432 & & 35. & & -495 & 2 & & 3 & $\$ 20$ & & -553 & $x_{1}$ & 56 & 55 & -534 & -555 \\
\hline & & & & & 65 & & & & -49 & & 4.66 & -4.85 & & 2,1 & & 1.83 & 4.75 & -6.95 & -59 & 35 & -59 & -7 & 63 \\
\hline & & & & & -7.75 & & -78 & -69 & -33 & -65 & \begin{tabular}{|l|}
-633 \\
\end{tabular} & \begin{tabular}{|l|l|} 
\\
\end{tabular} & -6163 & -69 & $-63 \overrightarrow{5}$ & $6 ! 74$ & 6.9 & -79 & & y & -7.6 & 7.7 & 7.6 \\
\hline$E$ & 7 & & & & \pm 7 & & & & & 5.65 & 35 & & & & & & & & $=2$ & 95 & 862 & 76 & 8.66 \\
\hline & $=$ & & & 31 & -9.4 & 35 & -9127 & -929 & -93 & $\begin{array}{r}1 \\
-94\end{array}$ & -95 & -9.6 & -9172 & -9.63 & $-957 \mid$ & -8.6 & -9.7 & 4 & -9.0 & & & & \\
\hline & 9 & 1.4 & 3 & 10.5 & \begin{tabular}{|l|}
-10.5 \\
\end{tabular} & -104 & 125 & 105 & 106 & $.146=$ & 105 & -105. & $-10_{4}$ & -102 & -106 & -164 & -104 & & \begin{tabular}{|l|}
-10.1 \\
\end{tabular} & -10.1 & 109 & 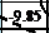 & \\
\hline & & & & -11.5 & $y=0$ & & -11.7 & -11.7 & $t r$ & \begin{tabular}{l|l}
$i .7$ \\
\end{tabular} & \begin{tabular}{|l|}
-119 \\
\end{tabular} & -11.4 & 11.4 & \begin{tabular}{|l|}
-113 \\
\end{tabular} & \begin{tabular}{|l|}
-119 \\
\end{tabular} & \begin{tabular}{|l|}
-113 \\
\end{tabular} & -11.7 & \begin{tabular}{|l|}
-11.1 \\
\end{tabular} & -Irza & 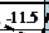 & -11.5 & -115 & -11 \\
\hline & 11 & 25 & 124 & -12.5 & $f^{12.5}$ & -125 & -127 & -126 & -127 & -126 & -127 & -126 & -128 & \begin{tabular}{|l|}
-127 \\
\end{tabular} & \begin{tabular}{|l|}
$-12 s$ \\
\end{tabular} & -127 & \begin{tabular}{|l|}
-12.6 \\
\end{tabular} & -125 & \begin{tabular}{|l|}
-124 \\
\end{tabular} & -124 & .12 .2 & -127 & \begin{tabular}{|l|}
-12.2 \\
\end{tabular} \\
\hline & & 9 & & -13.7 & $\mathbf{T}_{10.2}$ & 3.6 & 13.6 & -13.5 & 3.4 & 13.4 & -134 & -133 & 134 & 35 & \begin{tabular}{|l|}
-13.4 \\
\end{tabular} & -132 & 33 & \begin{tabular}{|l|l|}
-13.4 \\
\end{tabular} & \begin{tabular}{|l|}
-13.3 \\
\end{tabular} & $-13 \frac{1}{4}$ & -13.1 & $E+2$ & -13 \\
\hline & & 12 & $4^{4}$ & -14.2 & $-13 \mathrm{~s}$ & 7 & -14 & 4.1 & 42 & 1 & 14 & 14.1 & -13.8 & 3.7 & -12.7 & -13.6 & 35 & -135 & -13.4 & $+2=$ & 13.4 & -133 & \begin{tabular}{|l}
-13.3 \\
\end{tabular} \\
\hline & & & & -13.8 & \begin{tabular}{|l|}
-14 \\
\end{tabular} & -133 & $\pi 7$ & 13.6 & $=$ & $-11 T$ & $-1 \overline{4} . T$ & $-17 \bar{I}$ & 15.9 & $-13 \boldsymbol{I}$ & -13.7 & 75.9 & -13.7 & $-7 \sqrt{1}$ & -13.5 & -13.6 & 13.5 & & 9.3 \\
\hline & & & 1. & $-13: 14$ & 13.2 & 2) & -13 & $\begin{array}{r}-13.2 \\
\end{array}$ & -133 & -16.4 & -133 & -13 & $\begin{array}{r}-10.9 \\
\end{array}$ & \begin{tabular}{|l|}
-128 \\
\end{tabular} & \begin{tabular}{|l|}
-129 \\
\end{tabular} & -2.7 & -12. & -121 & -125 & & & 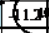 & $-1)^{3}$ \\
\hline & & & & 2.1 & -124 & & 7 & 426 & +27 & 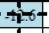 & 424 & - & $T$ & -418 & $-\mathrm{H}$ & \pm 2 & 42 & & -11.3 & -1164 & 4109 & -117 & -115 \\
\hline & & $x$ & & & 13 & 2 & -11.1 & -11.4 & -115 & -11.4 & -115 & -113 & -11 & -10.8 & \begin{tabular}{|l|} 
\\
\end{tabular} & -11 & \begin{tabular}{|l|l|}
-10.8 \\
\end{tabular} & -10.7 & \begin{tabular}{|l|l|} 
\\
\end{tabular} & -105 & -10.4 & -103 & -10 \\
\hline & & & & 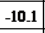 & 8 & & & -10 & 03 & 67 & 10.1 & -93 & -99 & 93 & & & & 85 & -95 & -9.4 & -9.45 & 93 & -9.25 \\
\hline $\mathbf{S}$ & & & & & 8.64 & & & 28 & 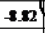 & & & 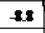 & تص & -8.7 & 8.69 & & & & 85 & 14 & 836 & 3.2 & 82 \\
\hline 1 & & & & 7 & 7 & & 3 & -7 & -7.6 & -75 & -75 & -7.63 & -7.6 & \begin{tabular}{|l|}
-75 \\
\end{tabular} & -7.4 & -73 & 32 & -725 & -7.4 & .44 & -75 & 7.4 & -735 \\
\hline & & & & & -6.1 & & -6.22 & -625 & & -6.2 & -6.25 & & -6.2 & & 1 & -536 & 2 & -53 & 9 & 8 & 59 & 535 & 5.6 \\
\hline & & & & 4 & 35 & & -4.42 & -4.43 & & -4.45 & 4 & -4.44 & -4.42 & -439 & -438 & -439 & -1 & -4.25 & -4.23 & 425 & -42 & 125 & -4.24 \\
\hline & & & & & 0 & & & & & -3.8 & -3.7 & -3 & -35 & -3.7 & -3.75 & -3.6 & & -3.4 & 3.45 & 35 & 3.4 & 3.42 & 325 \\
\hline 1 & & & & & - & & & & & 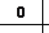 & & & & & -2 & -25 & & -27 & -23 & 65 & -26 & 2.4 & 22 \\
\hline & & & & & & & & & & & & & & & & & & & & & & 0 & 0 \\
\hline
\end{tabular}

Fig. 6. Ship maneuver in boom baru port basin

In that position the ship is still safe depth, they are ideal for navigation or maneuvering the ship, because it is still in the position of the middle course of the Musi river. When the ship began to move closer towards the dock, the ship's position is at a depth (h) of 8.66 meters (2014). Conditions such as these, would make the vessel must carefully maneuver, because the keel (the base) boat almost touch the bottom of the pool and could cause the ship run aground or sunk. In Figure 6 could also note that when the arrival of the vessel 
(Shipping-In), Musi river water level is at its lowest water level position (LLWL) and draft of the ship in a state of at least 7.24 meters. Seeing the condition of the depth (h) port basin ( +7 meters) and a maximum draft of vessels ( 7.24 meters) is certainly the vessel would not be able to sail safely and smoothly.

Activities maneuvering boat at the dock are also affected by the tidal conditions, which usually ships usually go or load and unload when the water level started to put the Musi river. To see the relationship between conditions of high surface activity with the activities of the Musi river ship maneuvering in port navigation channel in the pool can be explained as follows, the time of arrival at the dock ships usually morning from $06.00-12.00$, where the water depth reached +6 meters. When departure from the dock usually late afternoon towards evening ranged between the hours 18:00 to 00:00 pm, when the depth of the Musi river ranged from 6 meters up to 7 meters and at that time made directly loading and unloading of goods. But sometimes there are conducted in the morning, around $06.00 \mathrm{pm}$ when the water level of the Musi river at 6 meters - 7 meters and was completed during the day, at around 12:00 pm, and some even finished the afternoon at about 18:00 pm the water level Musi river reaches 6-7 meters. Based on observations of the activities of loading and unloading of ships at dock of Boom Baru port, the average time it takes each vessel at Terminal for the Interest Alone (TUKS), obtained an average as follows: (1) Turn Around Time (TRT) takes 123 hours and 21 minutes, or about 5 days; (2) While the effective time (ET) and the Operating Time (OT), takes 53 hours and 25 minutes, or about two and a half days; and (3) Bert Time (BT), the time it takes the ship from mooring rope (first line) until the loose rope (last line) takes 117 hours and 38 minutes, or about 5 days. Based on the three data, the level of efficiency when unloading the ship was approximately $77.55 \%$.

The volume of sediment that formed in Boom Baru port basin is +13081.42 m3/year. Based on available data, the depth of the port at low tide basin about 5-8 meters and +10 meters at high tide, so that when a ship with the highest draft or DWT (dead weight tons) ships up the process of navigation/maneuvering in the port basin have limitations, To cope with high sedimentation in the port basin and reduce duwelling time, because waiting for the tide, it is necessary to once a year dredging the port basin with a thickness of approximately $3 \mathrm{~m}$. The waiting time between the tide with the port basin depth in accordance with the needs of ship maneuvering average is 8 hours.

\section{Conclusion}

1.The rate of sedimentation on the Musi river about $+13,081.42 \mathrm{~m} 3 /$ year

2. Average Bert Time for each vessel is 117 hours 38 minutes

3. Time of arrival and departure is always carried out every morning until noon, when the water level around 7:24 am

\section{References}

1. L. Pinto, C.Munoz, T. Nalpaset all. Role of sedimentation during basin inversion in analogue modelling., Journal of Structural Geology Vol. 32, 554-565 (2010)

2. Yang,Chih Ted, Sediment Transport, Theory and Practice, Mc.Graw Hill, London (1996)

3. Z. Easton, D. Fuka, E. White et all, A multi basin SWAT model analysis of runoff and sedimentation in the Blue Nile, Ethiopia, Journal Hydrology and Earth System Sciences, Vol. 14, 1827-1841 (2010) 
4. S. Yang, Formula for Sediment Transport in Rivers, Estuaries, and Coastal Waters, Journal of Hydraulic Engineering Vol. 131, 968-979 (2005)

5. Yang Bai, JG. Duan, Simulating unsteady flow and sediment transport in vegetated channel network, Journal of Hydrology Vol. 515, 90-102 (2014)

6. C. Ribers, C. Kergaravat, C. Bonn et all, Fluvial sedimentation in a salt-controlled mini-basin: Stratal patterns and facies assemblages, Journal Sedimentology (2015)

7. M.Lazzari, D. Gioia, M. Piccarreta et all, Sediment yield and erosion rate estimation in the mountain catchments of the Camastra artificial reservoir (Southern Italy): A comparison between different empirical methods, Journal Catena Vol. 127, 323-339 (2015)

8. G. Figueredo De Olieviera, P. Cariou, The impact of competition on container port (in)efficiency, Transportation Research Part A: Policy and Practice (2015) 